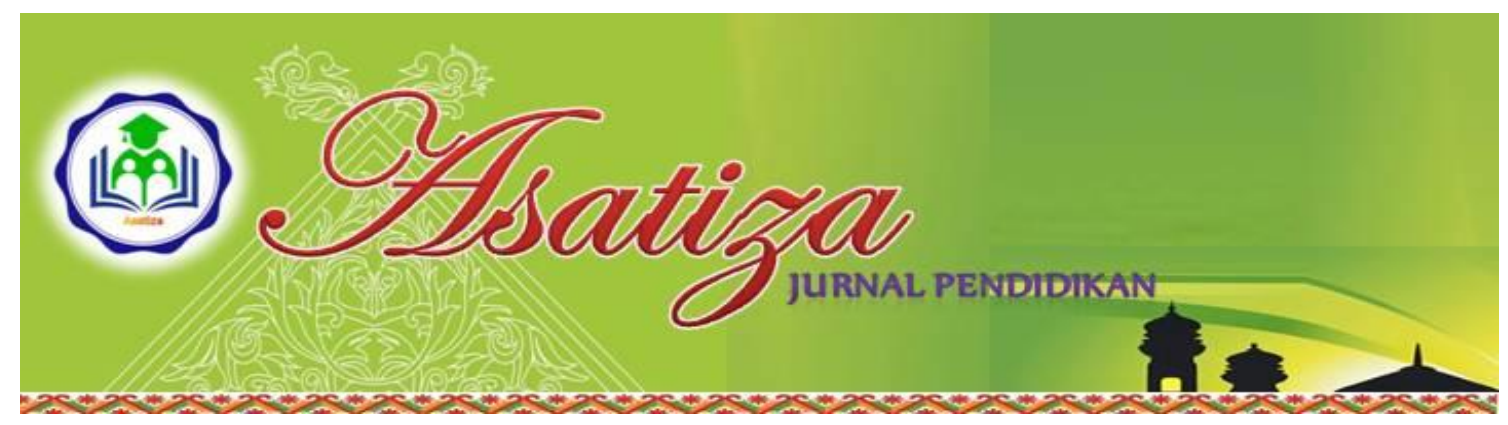

\title{
MENINGKATKAN HASIL BELAJAR SISWA MELALUI PENERAPAN MODEL PEMBELAJARAN COOPERATIVE SCRIPT PADA MATAPELAJARAN ILMU PENGETAHUAN SOSIAL KELAS VA SISWA SEKOLAH DASAR NEGERI O10 SUNGAI BERINGIN
}

\author{
Sari Mahdalena ${ }^{1}$; Moh. Sain ${ }^{2}$ \\ ${ }^{1}$ STAI Auliaurrasyidin Tembilahan, ${ }^{2}$ STAI Auliaurrasyidin Tembilahan
}

\begin{abstract}
Abstrak
Penelitian ini dilatarbelakangi oleh Rendahnya hasil belajar siswa kelas VA pada matapelajaran Ilmu Pengetahuan Sosial (IPS) di SD Negeri 010 Sungai Beringin yang dibuktikan dengan diperolehnya hasil rata-rata ulangan siswa tanggal 19 juli 2018 mencapai 56,25 dan ketuntasan belajar siswa mencapai $30 \%$ yang terdiri dari 6 orang siswa yanng mencapai KKM dan 14 orang yang tidak tuntas dengan jumlah siswa sebanyak 20 orang. Selain itu juga pembelajaran yang diterapkan menggunakan metode ceramah dan tanya jawab sehingaga kurang bervariasi. Hal tersebut memerlukan solusi yang tepat dengan menerapkan model pembelajaran Cooperative Script pada matapelajaran IPS sehingga dapat memaksimalkan hasil belajar siswa kelas VA. Tujuan penelitian ini adalah untuk mengetahui peningkatan hasil belajar siswa kelas VA pada matapelajaran Ilmu Pengetahuan Sosial dengan menerapkan model pembelajaran Cooperative Script di Sekolah Dasar Negeri 010 Sungai beringin.Penelitian ini merupakan jenis penelitian Tindakan kelas yang dilaksanakan di Sekolah Dasar Negeri 010 Sungai Beringin dengan berkolaborasi dengan guru matapelajaran IPS dengan jumlah siswa sebanyak 20 orang yang terdiri dari 15 laki-laki dan 5 orang perempuan. Penelitian ini menggunakan teknik pengumpulan data berupa observasi, tes, dan catatan lapangan.

Kesimpulan dari hasil penelitian ini telah terjadi peningkatan hasil belajar siswa kelas VA pada matapelajaran IPS dari prasiklus rata-rata hasil belajar mencapai 56,25 dengan persentase ketuntasan $30 \%$ dengan kategori kurang baik, rata-rata siklus 162.30 dengan persentase ketuntasan $45 \%$ dengan kategori cukup baik dan rata-rata siklus 2 mencapai 83,10 dengan persentase ketuntasan $95 \%$ dengan kategori sangat baik. Artinya penerapan model pembelajaran Cooperative Script dapat meningkatkan hasil belajar siswa kelas VA
\end{abstract}

Kata Kunci: Model Pembelajaran Cooperative Script, Hasil Belajar

\section{A. PENDAHULUAN}

\section{Latar Belakang}

Sekolah Dasar Negeri 010 Sungai Beringin merupakan salah satu sekolah dasar Negeri di wilayah Tembilahan yang menerapkan
Kurikulum 2013 yang merupakan salah satu peraturan yang dicanangkan pemerintah Indonesia demi tercapainya mutu pendidikan yang berkualitas, kurikulum 2013 adalah kurikulum yang menyederhana kan 
berbagai bentuk matapelajaran yang diintegrasikan dalam satu tema tertentu. Selain itu penilaian yang dilakukan dalam tiga aspek yaitu kognitif (pengetahuan), afektif (sikap) dan Psikomotor (keterampilan). Namun, penerapan kurikulum tersebut belum maksimal dan mengalami beberapa kendala dalam proses pelaksanaannya. Salah satu kendala tersebut dibuktikan dengan rendahnya hasil belajar siswa terutama pada aspek kognitif di Sekolah Dasar Negeri 010 Sungai Beringin dalam memahami matapelajaran terutama pada matapelajaran Ilmu Pengetahuan Sosial yang merupakan salah satu subjek matapelajaran yang diajarkan yang terintegrasi dalam dalam suatu tema seperti matapelajaranmatapelajaran lain dalam pelaksanaan kurikulum 2013. Menurut Ahmad Susanto mengatakan Ilmu Pengetahuan Sosial adalah perpaduan ilmu-ilmu sosial dan kehidupan manusia yang didalamnya mencakup antropologi, ekonomi, geografi, sejarah, hukum, filsafat, ilmu politik, sosiologi, agama, dan psikologi. Salah satu tujuan Ilmu Pengetahuan Sosial disekolah dasar adalah membekali anak didik dengan pengetahuan sosial yang berguna dalam kehidupan kelak dimasyarakat.

Berkaitan dengan hal di atas berdasarkan studi pendahuluan yang dilaksanakan tanggal 19 Juli 2018 peneliti melaksanakan Ulangan Harian dengan menyelenggakan tes tertulis bekerja sama dengan ibu Heffy Yani, S,Pd sebagai Guru Kelas VA sekaligus guru matapelajaran Ilmu Pengetahuan
Sosial berkaitan dengan materi tentang Letak Geografis Indonesia hasil belajar yan diperoleh oleh siswa kelas VA pada matapelajaran Ilmu pengetahuan Sosial tahun Ajaran 2018/2019 dengan Kriteria Ketuntasan Minimal (KKM) yang ditetapkan oleh sekolah yaitu 70 diperoleh bahwa hasil belajar siswa tergolong rendah dengan kategori kurang baik dengan persentase ketuntasan $30 \%$. Hal tersebut dapat disajikan dalam tabel berikut :

\begin{tabular}{|l|l|c|c|c|c|}
\hline \multirow{2}{*}{ NO } & \multirow{2}{*}{$\begin{array}{l}\text { Nama } \\
\text { Siswa }\end{array}$} & $\begin{array}{c}\text { K } \\
\text { K }\end{array}$ & Nilai & \multicolumn{2}{|c|}{ Kriteria } \\
\hline & & & Tuntas & $\begin{array}{c}\text { Tidak } \\
\text { Tuntas }\end{array}$ \\
\hline 1 & S1 & 70 & 70 & $\sqrt{ }$ & \\
\hline 2 & S2 & 70 & 65 & & $\sqrt{ }$ \\
\hline 3 & S3 & 70 & 65 & & $\sqrt{ }$ \\
\hline 4 & S4 & 70 & 70 & $\sqrt{ }$ & \\
\hline 5 & S5 & 70 & 0 & & $\sqrt{ }$ \\
\hline 6 & S6 & 70 & 50 & & $\sqrt{ }$ \\
\hline 7 & S7 & 70 & 65 & & $\sqrt{ }$ \\
\hline 8 & S8 & 70 & 65 & & $\sqrt{ }$ \\
\hline 9 & S9 & 70 & 90 & $\sqrt{ }$ & \\
\hline 10 & S10 & 70 & 65 & & $\sqrt{ }$ \\
\hline 11 & S11 & 70 & 75 & $\sqrt{ }$ & \\
\hline 12 & S12 & 70 & 10 & & $\sqrt{ }$ \\
\hline 13 & S13 & 70 & 30 & & $\sqrt{ }$ \\
\hline 14 & S14 & 70 & 10 & & $\sqrt{ }$ \\
\hline 15 & S15 & 70 & 95 & $\sqrt{ }$ & \\
\hline 16 & S16 & 70 & 45 & & $\sqrt{ }$ \\
\hline 17 & S17 & 70 & 65 & & $\sqrt{ }$ \\
\hline 18 & S18 & 70 & 50 & & $\sqrt{ }$ \\
\hline 19 & S19 & 70 & 55 & & $\sqrt{ }$ \\
\hline 20 & S20 & 70 & 85 & $\sqrt{ }$ & \\
\hline Jumlah & 20 & 1125 & 6 & 14 \\
\hline Rata-rata & & 56,25 & & \\
\hline Persentase & & & $30 \%$ & $70 \%$ \\
\hline
\end{tabular}

Sumber data: Hasil Ulangan Harian Prasiklus siswa Kelas VA

Berdasarkan data diatas berikut persentase nilai ketuntasan hasil belajar 
siswa subtema 1 tema 1 kelas VA semester 1 Tahun Ajaran 2018/2019

\begin{tabular}{|c|c|c|c|c|c|}
\hline \multicolumn{3}{|c|}{ Tuntas } & \multicolumn{3}{|c|}{ Tidak Tuntas } \\
\hline F & N & $\begin{array}{c}\text { Perse } \\
\text { ntase }\end{array}$ & F & N & $\begin{array}{c}\text { Perse } \\
\text { ntase }\end{array}$ \\
\hline 6 & 20 & $30 \%$ & 14 & 20 & $70 \%$ \\
\hline
\end{tabular}

Sumber Data : Hasil Ulangan Harian Prasiklus siswa Kelas VA Pada matapelajaran IPS

Rendahnya hasil belajar siswa kelas VA pada matapelajaran Ilmu Pengetahuan Sosial tersebut yang dibuktikan dengan perolehan rata-rata kelas 56,25 dalam kategori kurang baik disebabkan oleh metode yang digunakan oleh guru bersifat konfensional dan kurang bervariasi yaitu metode Ceramah, tanya jawab dan penugasan sehingga siswa merasa jenuh dalam belajar.

Untuk dapat mengatasi hal di atas banyak sekali metode serta model pembelajaran yang dikembangkan para ahli demi tercapainya pembelajaran yang bervariatif salah satu model yang dapat diterapkan adalah model pembelajaran Cooperative Script yang dapat dijadikan solusi sebagai pemecahan masalah berkaitan dengan masalah pembelajaran disekolah Dasar. Menurut Asih, mengacu pada Departemen Pendidikan Nasional ada beberapa model pembelajaran yang efektif $^{1}$ yang dapat digunakan. Salah satu model yang dapat digunakan adalah model pembelajaran Cooperative Script.Menurut Hamdani, model pembelajaran Cooperative Sript adalah metode belajar yang mengarahkan siswa untuk bekerja berpasangan secara lisan mengikhtisarkan bagian bagian dari materi yang dipelajari ${ }^{2}$.

${ }^{1}$ Asih. Strategi Pembelajaran Bahasa Indonesia. (Bandung: Pustaka Setia), hal. 13-17
Dengan menggunakan model pembelajaran tersebut, diharapkan akan dapat memudahkan siswa memahami materi yang diajarkan. Apabila siswa memahami materi pelajaran maka akan dapat meningkatkan hasil belajar siswa. Berdasarkan batasan masalah diatas dapat dirumuskan permasalahan yaitu:

a. Bagaimana hasil belajar siswa pada matapelajaran Ilmu Pengetahuan Sosial kelas VA siswa Sekolah Dasar Negeri 010 Sungai Beringin?

b. Bagaimana penerapan model pembelajaran Cooperative Script pada matapelajaran Ilmu Pengetahuan Sosial dalam meningkatkan hasil belajar siswa Kelas VA SDN 010 Sungai Beringin?

c. Bagaimanapenerapan model Pembelajaran Cooperative Script dalam meningkatkan hasil belajar kelasVApada mata pelajaran Ilmu Pengetahuan Sosial siswa Sekolah Dasar Negeri 010 Sungai Beringin?

\section{Pengertian Ilmu Pengetahuan \\ Sosial}

Ilmu Pengetahuan Sosial sering disingkat dengan IPS adalah salah satu ilmu pengetahuan yang mengkaji berbagai disiplin ilmu yang dikemas secara ilmiah yang bertujuan memberikan wawasan serta pengetahuan kepada peserta didik khususnya di tingkat dasar ${ }^{3}$. Menurut Ahmad Susanto,hakikat Ilmu Pengetahuan sosial adalah :"untuk mengembangkan konsep pemikiranyang berdasarkan realita kondisi sosial yang ada dilingkungan siswa sehingga dengan memberikan pendidikan IPS diharapkan

\footnotetext{
${ }^{2}$ Hamdani. Strategi Belajar Mengajar. (Bandung: Pustaka Setia, 2011), hal. 88

${ }^{3}$ Ahmad Susanto.Op. Cit, hal. 137
} 
dapat melahirkan warga negara yang baik dan bertanggung jawab terhadap bangsa dan negaranya". 4

Jadi, dapat disimpulkan bahwa hakikat Ilmu Pengetahuan Sosial hendaknya dikembangkan berdasarkan realita kondisi sosial budaya yang ada dilingkungan siswa sehingga dapat membina peserta didik menjadi warga negara yang bertanggung jawab serta dapat menelaah secara kritis kehidupan sosial disekitar lingkungan tempat tinggal mereka dengan mengembangkan nilainilai edukatif, praktis serta teoritis. Nilainilai tersebut berguna menyiapkan peserta didik menjadi anggota masyarakat dimasa yang akan datang baik dimasyarakatnya, negara maupun dunia.

Dalam Kurikulum Pendidikan Dasar Tahun 2013, disebutkan bahwa Ilmu Pengetahuan Sosial adalah matapelajaran yang mempelajari kehidupan sosial yang didasarkan pada bahan kajian geografi, ekonomi,sejarah, antropologi, sosiologi, dan tata negara. Khusus di sekolah lanjutan tingkat pertama program pengajaran IPS hanya mencakup bahan kajian geografi, ekonomi dan sejarah. ${ }^{5}$

BuchariAlma dalam Ahmad Susanto, mengemukakan pengertian Ilmu Pengetahuan Sosial sebagai suatu program pendidikan yang merupakan suatu keseluruhan yang pada pokoknya mempersoalkan manusia dan lingkungan fisiknya maupun dalamlingkungan sosialnya dan yang bahannya diambil dari berbagai ilmu sosial seperti: geografi,

\footnotetext{
${ }^{4}$ Ibid, Hal. 137-138

${ }^{5}$ Kurikulum Pendidikan dasar 1993 dalam Ahmad Susanto, ibid, hal. 139
}

sejarah, ekonomi, antropologi, sosiologi, politik, dan psikologi. ${ }^{6}$

Berikut ini pengertian IPS yang dikemukakan oleh beberapa ahli pendidikan IPS di Indonesia: ${ }^{7}$

- Moeljono Cokrodikarjo mengemuka kan bahwa IPS adalah perwujudan dari suatu pendekatan Interdisiplinerdari ilmu sosial. Ia merupakan integrasi dari berbagai cabang ilmu sosial yakni sosiologi, antropologi budaya, psikologi, sejarah, geografi, ekonomi, ilmu politik, dan ekologi manusia, yang diformulasikan untuk tujuan intruksional dengan materi dan tujuan yang disederhanakan agar mudah dipelajari.

- Numan Sumantri menyatakan bahwa IPS adalah pelajaran ilmu-ilmu Sosialyang disederhanakan untuk pendidikan tingkat SD, SLTP, dan SLTA.

- S. Nasution mendefenisikan IPS sebagai pelajaran yang merupakan pelajaran yang merupakan fusi atau paduan sejumlah mata pelajaran sosial.Dinyatakan bahwa IPS merupakan bagian kurikulum sekolah yang berhubungan dengan peran manusia dalam masyarakat yang terdiri atas berbagai subjek sejarah, ekonomi, geogragi, sosiologi, antropologi dan psikologi sosial.

Berdasarkan beberapa pendapat ahli pendidikan diatas, dapat dipahami bahwa Ilmu Pengetahuan Sosial adalah matapelajaran yang merupakan

\footnotetext{
${ }^{6}$ Buchari Alma dalam Ahmad Susanto, Ibid, hal 141

${ }^{7}$ Modul IPS, hal. 1-10
} 
perintegrasian, perpaduan, perwujudan dari berbagai ilmu-ilmu sosial dan kehidupan manusia yang terdiri dari antropologi, ekonomi, sejarah, geografi, sosiologi,ilmu politik dan tata negara.

Antropologi adalah ilmu yang mempelajari segala wujud hasil budaya manusia dalam menjaga eksistensi nya dan usaha meningkatkan kehidupan baik dalam aspek lahiriah maupun batiniah serta mempelajari kebudayaan umat manusia dalam hubungan kelompok dan ruang.

Secara perinci, Mutikan dalam Ahmad Susanto, merumuskan tujuan Ilmu Pengetahuan Sosial di Sekolah sebagai berikut ${ }^{8}$ :

a. Memiliki kesadaran dan kepedulian terhadap masyarakat atau lingkungannya melalui pemahaman terhadap nilai-nilai sejarah dan kebudayaan masyarakat.

b. Mengetahui dan memahami konsep dasar dan mampu menggunakan metode yang diadaptasi dari ilmuilmu sosial yang kemudian dapat digunakan untuk memecahkan masalah-masalah sosial.

c. Mampu menggunakan model-model dan proses berfikir serta membuat keputusan untuk menyelesaikan isu dan masalah yang berkembang dimasyarakat.

d. Menaruh perhatian terhadap isu-isu dan masalah masalah sosial, serta mampu membuat analisis yang kritis, selanjutnya mampu mengambil tindakan yang tepat. 168

${ }^{8}$ Mutikan dalam Ahmad Susanto. Op.Cit, hal.

${ }^{9}$ Hamid Hasan dalam Ahmad Susanto. Ibid, hal. 147 e. Mampu mengembangkan berbagai potensi sehingga mampu membangun diri sendiri agar survive yang kemudian bertanggung jawab membangun masyarakat.

Hamid Hasan dalam Ahmad Susanto, membagi tujuan Ilmu Pengetahuan Sosial dalam tiga kategori sebagai berikut ${ }^{9}$ :

a. Pengembangan kemampuan intelektual siswa yang berorientasi pada kemampuan intelektual yang berhubungan dengan diri siswa.

b. Pengembangan kemampuan dan rasa tanggung jawab sebagai anggota masyarakat dan bangsa berorientasi pada pengembangan diri siswa dan kepentingan masyarakat yang dinamakan kemampuan sosial.

c. Pengembangan diri secara pribadi, berorientasi pada pengembangan peribadi siswa baik untuk kepentingan dirinya, masyarakat maupun ilmu.

Adapun tujuan Ilmu Pengetahuan Sosial di Sekolah dasar menurut Munir dalam Ahmad Susanto, sebagai berikut ${ }^{10}$ : a. Membekali peserta didik dengan pengetahuan sosial yang berguna dalam kehidupan kelak dimasyarakat.

b. Membekali peserta didik dengan kemampuan mengidentifikasi, menganalisis, dan menyusun alternatif pemecahan masalah sosial yang terjadi dalam kehidupan masyarakat.

\footnotetext{
${ }^{10}$ Munir dalam Ahmad Susanto. Ibid, hal. 150-
} 151 
c. Membekali peserta didik dengan kemampuan komunikasi dengan sesama warga masyarakat dan dengan berbagai bidang keilmuan serta bidang keahlian.

d. Membekali peserta didik dengan kesadaran, sikap mental yang positif, dan keterampilan terhadap lingkungan hidup yang menjadi bagian kehidupannya yang tidak dapat dipisahkan.

e. Membekali peserta didik dengan kemampuan mengembangkan pengetahuan dan keilmuan IPS sesuai dengan perkembangan kehidupan, perkembangan masyarakat, dan perkembangan Ilmu Pengetahuan dan teknologi.

Kelimatujuan diatas, harus dicapai dalam pelaksanaan kurikulum IPS diberbagai lembaga pendidikan termasuk di jenjang sekolah dasar. ${ }^{11}$

\section{Ruang Lingkup Ilmu \\ Pengetahuan Sosial}

Secara mendasar,IPS berkenaan dengan kehidupan manusia yang melibatkan segala tingkah laku dan kebutuhannya. IPS berkenaan dengan cara manusia memenuhi kebutuhannya baik untuk memenuhi kebutuhan materi, budaya dan kejiwaannya, memanfaatkan sumber daya yang ada dipermukaan bumi, mengatur kesejahteraan dan pemerintahannya maupun kebutuhsn lainnya dalam rangka mempertahankan kehidupan masyarakat manusia. Singkatnya, IPS mempelajari, menelaah, dan mengkaji sistem kehidupan manusia dipermukaan bumi dalam konteks sosialnya atau manusia sebagai anggota masyarakat.

Dengan pertimbangan bahwa manusia dalam konteks sosial demikian luas, pengajaran IPS pada jenjang pendidikan harus dibatasi sesuai dengan kemampuan peserta didik tiap jenjang sehingga pengajaran IPS pada jenjang pendidikan dasar berbeda dengan jenjang pendidikan menengah dan pendidikan tinggi.

Pada jenjang pendidikan dasar ruang lingkup pengajaran IPS dibatasi sampai pada gejala dan masalah sosial yang dapat dijangkau pada geografi dan sejarah. Terutama gejala dan masalah sosial kehidupan sehari hari yang ada dilingkungan sekitar peserta didik $\mathrm{MI} / \mathrm{SD}{ }^{12}$

Indikator fokus bahasan dalam ruang lingkup Ilmu Pengetahuan Sosial sesuai dengan kajian ilmu pengetahuan sosial disekolah dasar adalah mengenai geografi. Berikut konsep dasar Geografi beserta ruang lingkupnya antara lain :

\begin{tabular}{|c|c|}
\hline $\begin{array}{l}\text { Konsep dasar } \\
\text { disiplin ilmu }\end{array}$ & $\begin{array}{l}\text { Generalisasi Ilmu } \\
\text { pengetahuan Sosial }\end{array}$ \\
\hline $\begin{array}{l}\text { Geografi, lokasi } \\
\text { wilayah,interaksi } \\
\text { kerusangan, pola } \\
\text { keruangan,lingku } \\
\text { ngan, manusia, } \\
\text { struktur internal } \\
\text { kota dll. }\end{array}$ & $\begin{array}{l}\text { - Gografi adalah studi } \\
\text { tentang penyebaran } \\
\text { gejala- gejala pada } \\
\text { ruang bumi } \\
\text { - Garis lintang, bujur, } \\
\text { arah, skala, dan jarak } \\
\text { - Lokasi dipermukaan } \\
\text { bumi ditentukan oleh } \\
\text { kondisi alam, tata } \\
\text { lingkungan, sumber } \\
\text { daya } \\
\text { - Interaks antar bangsa } \\
\text { dapat terjadi bila } \\
\text { gagasan, prilaku, dan } \\
\text { objek penyebab dapat } \\
\text { dapat menyebar dalam } \\
\text { masyarakat }\end{array}$ \\
\hline
\end{tabular}

\footnotetext{
${ }^{12}$ Modul IPS, Op. Cit, hal. 1-11
}

${ }^{11}$ Ahmad Susanto, Op. Cit, hal. 150-151 


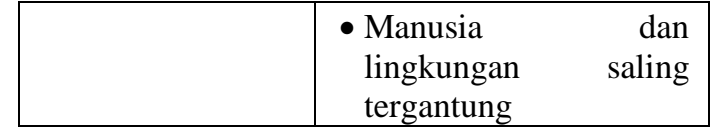

Geografi adalah berasal dari dari bahasa yunani yaitu Geographika. Kata Geo berarti bumi dan graphien berarti tulisan, lukisan. Dengan demikian geografi adalah ilmu pengetahuan yang menuliskan, melukiskan dan mencitrakan tentang bumi beserta kehidupan yang ada diatasnya. Kajian geografi mempunyai ruang lingkup yang luas sehingga disiplin ilmu lainnya banyak berkaitan dengan gegrafi. Keterkaitan geografi dengan disiplin ilmu lain dapat dibedakan menurut aspek fisik yang disebut geografi fisik dan aspek sosial disebut geografi sosial.

Objek geografi fisik merupakan kajian yang secara khusus membahas unsur-unsur alam mengenai bumi menyangkut tanah, udara, air, relief, iklim dan semua fenomena alam yang langsung dapat diamati. Sedangkan objek geografi sosial merupakan kajian yang secara khusus membahas tentang kehidupan manusia seperti jumlah penduduk, penyebaran penduduk, kepadatan penduduk, kegiatan ekonomi, dan segala aspek yang berhubungan dengan pola hidup manusia ${ }^{13}$.

\section{Materi Pelajaran Ilmu Pengetahuan Sosial}

Materi pelajaran merupakan isi atau bahan yang akan dipelajari oleh siswa harus dipersiapkan dengan baik untuk disampaikan kepada siswa ${ }^{14}$. Jika ditelaah lebih lanjut menurut Abdul

\footnotetext{
${ }^{13}$ Ibid, hal. 8.10

${ }^{14}$ Ahmad Susanto. Op.Cit,hal. 132

${ }^{15}$ Abdul Majid dan Chairul Rochman. Pendekatan Ilmiah dalam Implementasi Kurikulum
}

Majid dan Chaerul Rochman dalam Pendekatan Ilmiah Dalam Implementasi Kurikulum 2013dikelas V nama mata pelajaran IPA dan IPS tercantum dan memiliki kompetensi dasar masingmasing. Untuk Proses pembelajaran Kompetensi dasar IPA dan IPS sebagaimana kompetensi dasar matapelajaran lain diintegrasikan dalam berbagai tema. Oleh karena itu, proses pembelajaran semua kompetensi dasar dari semua mata pelajaran terintegrasi dalam berbagai tema ${ }^{15}$.

Berdasarkan uraian tersebut,Ilmu Pengetahuan Sosial dalam pelaksanaan kurikulum 2013 dikelas V terintegrasi dalam sebuah tema dalam mata pelajaran, namun Kompetensi Dasar IPS berdiri sendiri, yang kemudian diintegrasi kedalam tema-tema yang ada.

Kompetensi dasar adalah kompetensi setiap mata pelajaran untuk setiap kelas yang diturunkan dari Kompetensi Inti. Kompetensi dasar adalah konten atau kompetensi yang terdiri sikap, pengetahuan dan keterampilan yang bersumber dari kompetensi inti yang harus dikuasai oleh peserta didik. Kompetensi inti adalah terjemahan atau operasional SKL dalam bentuk kualitas yang harus dimiliki mereka telah menyelesaikan pendidikan pada suatu satuan pendidikan tertentu ${ }^{16}$.

\section{Model Pembelajaran Cooperative Script}

Salah satu model pembelajaran yang dapat digunakan dalam mencapai tujuan

2013. (Bandung: Remaja Rosdakarya, 2014), hal. 21-24

${ }^{31}$ Abdul Majid dan Chairul Rochman. Ibid, hal. 30 
pembelajaran adalah model pembelajaran kooperatif. Model pembelajaran kooperatif menurut Johnson adalah pengelompokkan siswa didalam kelas kedalam suatu kelompok kecil agar siswa dapat bekerja dengan kemampuan maksimal yang mereka miliki dan mempelajari satu sama lain dalam kelompok tersebut. Menurut Dariyanto,model pembelajaran kooperatif adalah model pembelajaran dengan setting kelompok-kelompok kecil yang terdiri 4-5 orang untuk memahami konsep yang difasilitasi oleh guru dengan memperhatikan keberagaman anggota kelompok sebagai wadah siswa untuk bekerja sama dan memecahkan masalah melalui interaksi sosial dengan teman sebayanya. Tujuan dari model pembelajaran kooperatif adalah menciptakan situasi dimana keberhasilan individu ditentukan atau dipengaruhi keberhasilan kelompoknya.

Unsur-unsur dasar dalam model pembelajaran kooperatif menurut Lungdren, sebagai berikut ${ }^{17}$ :

a. Para siswa harus memiliki persepsi bahwa mereka tenggelam atau berenang bersama.

b. Para siswa memiliki tanggung jawab terhadap siswa lain dalam kelompoknya, selain tanggung jawab terhadap diri sendiri dalam mempelajari materi yang dihadapi.

c. Para siswa harus berpandangan bahwa mereka semua memiliki tujuan yang sama.

d. Para siswa membagi tugas dan berbagi tanggung jawab diantara para anggota kelompok. e. Para siswa di berikan suatu evaluasi atau penghargaan yang akan ikut berpengaruh terhadap evaluasi kelompok.

f. Para siswa berbagi kepemimpinan sementara mereka memperoleh keterampilan bekerja sama selama belajar.

Isjoni dalamWahyudi,
terdapat lima ciri model
pembelajaran kooperatif meliputi:

a. Adanya peran yang dimiliki oleh setiap anggota didalam proses pembelajaran.

b. Terciptanya interaksi antar siswa secara langsung.

c. Masing-masing anggota memiliki tanggung jawab atas proses belajarnya dan anggota lain dalam kelompoknya.

d. Guru berperan sebagai fasilitator dalam mengembangkan keterampilan interpersonal siswa kelompok.

e. Peran guru sebagai fasilitator dalam proses pembelajaran dilakukan secara efektif dan efisien ketika melakukan interaksi dengan peserta didik.

Salah satu model Pembelajaran kooperatif yang dapat diterapkan dalam pembelajaran adalah model pembelajaran Cooperative Script ${ }^{18}$. Menurut Asih dalam buku karangannya yang berjudul Strategi Pembelajaran, Mengacu pada Departemen Pendidikan Nasional ada beberapa model pembelajaran yang efektif salah satunya Cooperative Script. Dansere dalam Asih, model pembelajaran Cooperative Script adalah siswa bekerja

\footnotetext{
${ }^{18}$ Hamdani, Op. Cit, hal 88
} 
dalam kelompok dan bergantian secara lisan mengihtisarkan bagian bagian dari materi yang dipelajari ${ }^{19}$. Jadi, berdasarkan pendapat yang dikemukakan asih yang didalamnya dikutip pendapat dari Densere yang dikutip didalamnya dapat dipahami bahwa Cooperative Script termasuk dalam jenis model pembelajaran kooperatif. Menurut Lambiotte dalam Miftahul Huda dalam buku model-model pengajaran dan pembelajaran, menjelaskan bahwa model pembelajaran Cooperative Script adalah salah satu strategi Pembelajaran dimana siswa bekerja secara berpasangan dan bergantian secara lisan dalam mengikhtisarkan bagian-bagian materi yang dipelajari ${ }^{20}$.

Berdasarkan penjelasan diatas, dapat dipahami bahwa model pembelajaran Cooperative Script adalah metode, strategi, taktik, pendekatan, teknik dan taktik belajar yang dilakukan dengan cara membentuk siswa secara berkelompok berpasangan untuk memahami dan membuat ringkasan tentang materi pelajaran yang akan dipelajari serta secara bergantian mendapat peran sebagai pembaca dan pendengar untuk membacakan ringkasan yang telah dibuat.

Jadi, berdasarkan penjelasan para ahli diatas peneliti menetapkan bahwa Cooperative script dapat dikatakan sebagai model pembelajaran yang dapat digunakan didalam proses pembelajaran sesuai dengan pendapat yang dikemukakan oleh Asih yang merupakan

\footnotetext{
${ }^{19}$ Dansere dalam Asih, Op. Cit, hal. 139

${ }^{20}$ Miftahul Huda. Model-model Pengajaran dan Pembelajaran. ( Yogyakarta: Pustaka Pelajar, 2014) cetakan V, hal.213
}

model pembelajaran yang efektiif digunakan untuk mencapai tujuan pembelajaran. Kemudian, diperkuat lagi oleh Agus Suprijono penulis sependapat bahwa model pembelajaran Cooperative Script merupakan salah satu model pembelajaran kooperatif.

\section{Langkah-langkah \\ Model Pembelajaran Cooperative Script}

Menurut Hamdani dalam kutipan buku Setrategi Belajar Mengajar, langkah-langkah pelaksanaan model pembelajaran Cooperative Script sebagai berikut $^{21}$ :

a. Membagi siswa untuk berpasangan.

b. Guru membagikan wacana/materi kepada siswa untuk dibaca dan membuat ringkasan.

c. Guru dan siswa menetapkan siapa yang pertama berperan sebagai pembicara dan siapa siswa yang berperan sebagai pendengar.

d. Pembicara membacakan ringkasannya selengkap mungkin,dengan memasukkan ide ide pokok dalam ringkasannya, Sementara pendengar menyimak dan mengoreksi atau menunjukkan ide-ide pokok yang kurang lengkap dan membantu mengingat atau menghapal ide-ide pokok dengan menghubungkan materi sebelumnnya dengan materi sebelumnya atau dengan materi lainnya.

e. Bertukar peran. Siswa yang semula sebagai pembicara ditukar menjadi pendengar dan sebaliknya.

\footnotetext{
${ }^{21}$ Hamdani. Op. Cit, hal. 88
} 
f. Guru Membuat Kesimpulan

Pendapat yang sama juga dikemukakan oleh Asih dalam Buku Strategi Pembelajaran Bahasa yang menyatakan langkah-langkah pembelajaran Cooperative Script. Sejalan dengan pendapat Asih ${ }^{22}$, Agus Suprijono menyatakan langkah yang sama mengenai Cooperative Script sebagai berikut ${ }^{23}$ :

a. Guru membagi siswa dalam kelompok berpasangan.

b. Guru memberikan wacana atau materi kepada siswa untuk dibaca dan membuat ringkasan.

c. Guru dan siswa menetapkan siswa yang pertama berperan sebagai pendengar.

d. Pembicara membacakan ringkasannya. Sementara pendengar menyimak, mengoreksi, menunjukkan ide-ide pokok yang kurang lengkap, membantu/mengingat/ menghapal ide pokok dengan menghubungkan materi sebelumnya dengan materi lainnya.

e. Siswa bertukar peran, yang semula sebagai pembicara menjadi pendengar dan sebaiknya. Serta lakukan itu seterusnya

f. Siswa bersama guru membuat kesimpulan

g. Penutup

Jadi, berdasarkan beberapa

langkah-langkah model pembelajaran Cooperative Script yang dikemukakan oleh para ahli diatas tentang langkah-langkah model Pembelajaran Cooperative

Scriptpeneliti menggunakan indikator langkah-langkah yang dikemukakan oleh Asih yang menyatakan langkah-langkah model pembelajaran Cooperative Script sebagai berikut :

a. Gurumembagi siswa dalam kelompok berpasangan.

b. Guru memberikan wacana atau materi kepada siswa untuk dibaca dan membuat ringkasan.

c. Guru dan siswa menetapkan siswa yang pertama berperan sebagai pendengar.

d. Pembicara membacakan ringkasannya. Sementara pendengar menyimak, mengoreksi, menunjukkann ide-idepokok yang kurang lengkap, membantu/mengingat/mengha palide pokok dengan menghubungkan materi sebelumnya dengan materi lainnya.

e. Siswa bertukar peran, yang semula sebagai pembicara menjadi pendengar dan sebaiknya. Serta lakukan itu seterusnya.

f. Siswa bersama guru membuat kesimpulan.

g. Penutup.

${ }^{22}$ Asih. Op. Cit. hal. 139

${ }^{23}$ Agus Suprijono. Cooperative

Learning.(Yogyakarta: Pustaka Pelajar, 2013), hal. 126-127 
6. Kelebihan dan kekurangan Model Pembelajaran Cooperative Script

Menurut Hamdani, ada beberapa kelebihan dan kekurangan model pembelajaran Cooperative Script diantaranya ${ }^{24}$ :

a. Kelebihan

1) MelatihPendengaran, ketelitian atau kecermatan

2) Setiap siswa mendapat peran

3) Melatih mengungkapkan kesalahan orang lain

b. Kelemahan

1) Hanya digunakan pada mata pelajaran Tertentu

2) Hanya dilakukan oleh dua orang

Menurut Miftahul Huda, menjelaskan model pembelajaran Cooperative Script memiliki beberapa kelebihan diantaranya ${ }^{25}$ :

1) Dapat menumbuhkan ide-ide atau gagasan baru, daya berfikir kritis, serta mengembangkan jiwa keberanian dalam menyampaikan hal-hal baru yang diyakini dengan benar.

2) Mengajarkan siswa untuk percaya kepada guru dan lebih percaya lagi pada kemampuan sendiri untuk berfikir, mencari informasi dari sumber lain dan belajar dari siswa lain.

3) Mendorong siswa untuk berlatih memecahkan masalah dengan mengungkapkan idenya secara verbal dan membandingkan ide siswa dengan ide temannya.

${ }^{24}$ Hamdani.Loc. Cit. hal. 89

${ }^{25}$ Miftahul Huda. Op.Cit. Hal. 213
4) Membantu siswa belajar menghormati siswa yang pintar dan siswa yang kurang pintar serta menerima perbedaan yang ada.

5) Memotivasi siswa yang kurang pandai agar mampu mengungkapkan pemikirannya.

6) Memudahkan siswa berdiskusi dan melakukan interaksi social.

7) Meningkatkan kemampuan berfikir kreatif.

Kelemahan model pembelajaran Cooperative Scriptmenurut Miftahul Huda, antara lain ${ }^{26}$ :

1) Ketakutan siswa untuk mengeluarkan ide karena akan dinilai oleh teman dalam kelompoknya.

2) Ketidakmampuan semua siswa untuk menerapkan strategi ini sehingga banyak tersisa untuk menjelaskan mengenai model pembelajaran ini.

3) Keharusan guru untuk melaporkan setiap penampilan siswa dan tiap tugas siswa untuk menghitung hasil prestasi kelompok dan ini bukan tugas yang sebentar.

4) Kesulitan membentuk kelompok yang solit dan dapat bekerja sama dengan baik.

5) Kesulitan menilai siswa sebagai individu karena mereka berada dalam kelompok.

7. Hasil Belajar Kognitif (Pengetahuan)

Hasil belajar yaitu perubahanperubahan yang terjadi pada diri siswa, baik menyangkut aspek

${ }^{26}$ Ibid, hal. 215 
kognitif (pengetahuan), Afektif (Sikap), dan psikomotor sebagai hasil dari kegiatan belajar.

Nawawi dalam K.Brahim dalam buku Ahmad Susanto, menyatakan bahwa hasil belajar dapat diartikan sebagai tingkat keberhasilan siswa dalam mempelajari materi pelajaran di sekolah yang dinyatakan dalam skor yang diperoleh dari hasil tes mengenai sejumlah materipelajaran tertentu. ${ }^{27}$

Secara sederhana, yang dimaksud dengan hasil belajar siswa adalah kemampuan yang diperoleh anak setelah melalui kegiatan belajar. Karena belajar itu sendiri merupakan suatu proses dari seseorang yang berusaha untuk memperoleh suatu bentuk perubahan perilaku yang lebih menetap.

Jadi, berdasarkan beberapa pendapat mengenai uraian diatas dapat dipahami bahwa hasil belajar merupakan suatu perubahan yang diperoleh oleh peserta didik setelah mengikuti kegiatan pembelajaran dikelas yang dinyatakan dalam aspek kognitif, afektif dan psikomotorik dan juga tingkat keberhasilan yang diperoleh peserta didik dalam memahami materi bahan isi pelajaran yang diajarkan yang dinyatakan dalam bentuk skor sesuai dengan kompetensi yang dicapainya.

Benyamin Bloom, secara garis besar membagi hasil belajar menjadi tiga ranah

\footnotetext{
${ }^{27}$ Nawawi dalam K. Brahim dalamAhmad Susanto. Loc. Cit, hal. 5

${ }^{28}$ Rini Anggraini. Pengaruh Penerapan Media Gambar Fotografi Terhadap Hasil Belajar Siswa pada Mata Pelajaran IPA Kelas V di Madrasah Ibtidaiyah Tarbiyah Islamiyah Palembang. Jurnal
}

yakni ranah kognitif, ranah afektif, ranah psikomotoris. Ranah kognitif berkenaan dengan hasil belajar intelektual yang terdiri dari enam aspek yakni pengetahuan atau ingatan, pemahaman, aplikasi, analisis, sintesis, dan evaluasi. Ranah afektif berkenaan dengan sikap yang terdiri dari lima aspek yakni penerimaan, jawaban,penilaian, organisasi, dan internalisasi. Ranah psikomotoris berkenaan dengan hasil belajar keterampilan dan kemampuan bertindak $^{28}$.

Hasil belajar dapat diklasifisikasi menjadi tiga, yaitu: ${ }^{29}$

a. Keefektifan

Keefektifan pembelajaran biasa diukur dengan tingkat pencapaian peserta didik. Keefektifan pembelajaran biasanya diukur dengan tingkat pencapaian isi belajar.Ada empat aspek penting yang dapat dipakai untuk mendeskripsikan keefektifan belajar, yaitu 1. Kecermatan penguasan perilaku yang dipelajari/ kesalahan. 2. Kecepatan unjuk kerja. 3. Tingkat Alih belajar. 4. Tingkat retensi apa yang dipelajari.

b. Efesiensi

Efesiensi pembelajaran biasanya diukur dengan rasio antara keefektifan dan jumlah waktu yang digunakan peserta didik atau jumlah biaya yang digunakan ${ }^{30}$.

Ilmiah PGMI. Fakultas Ilmu Tarbiyah dan Keguruan Universitas Islam Negeri Raden Fatah Palembang.2016. Volume 2 No 1, hal. 61

${ }^{29}$ Hamzah B. Uno. Perencanaan Pembelajaran. (Jakarta: Bumi Aksara, 2006), hal. 21

${ }^{30}$ Asih.Loc. Cit, hal. 17 
c. Daya tarik pembelajaran

Daya tarik pembelajaran biasanya diukur dengan mengamati kecendrungan siswa untuk tetap belajar. Daya tarik pembelajaran erat sekali kaitannya dengan daya tarik bidang studi, dimana kualitas pembelajaran biasanya akan mempengaruhi keduanya ${ }^{31}$

Menurut Nana Sudjana, ketiga ranah tersebut menjadi objek penilaian hasil belajar. Diantara ketiga ranah tersebut, ranah kognitiflah yang paling banyak dinilai oleh para guru disekolah karena berkaitan dengan kemampuan siswa dalam menguasai isi bahan pengajaran. Yang menjadi indikator yang akan hasil belajar dalam ketiga ranah tersebut adalah Ranah kognitif ${ }^{32}$.

Menurut Muhammad Yaumi,ranah kognitif mengacu pada aktivitas mental dimana suatu pendekatan terfokus pada proses penyampaian informasi dan penanaman konsep-konsep baru untuk memahami hubungan antar konsep. Informasi dipecah dan dibangun kembali dengan koneksi logis sebagai hasilnya retensi dan daya ingat tentang materi menjadi meningkat. Ranah kognitif adalah suatu ranah kemampuan berfikir tentang fakta-fakta spesifik, pola prosedural, dan konsep-konsep dalam mengembangkan pengetahuan dan keterampilan intelektual.

Bloom merumuskan taksonomi pembelajaran khususnya dalam ranah kognisi mulai dari keterampilan berfikir tigkat rendah hingga sampai keterampilan berfikir tingkat tinggi atau

\footnotetext{
${ }^{31}$ Hamzah. B. Uno. Op. Cit. hal. 21
}

mulai dari tingkat pengetahuan, pemahaman, aplikasi, dan analisis yang digolongkan dalam keterampilan berfikir tingkat rendah sampai tingkat sintesis dan evaluasi yang merupakan keterampilan berfikir tingkat tinggi.

Menurut Hubbell yang dikutip dalam Muhammad Yaumi, menjelaskan lebih jauh bahwa pengetahuan berdasarkan pengalaman adalah untuk mengungkap jawaban dari pertanyaan, mengapa sesuatu itu penting, pengetahuan kontektual berfungsi untuk mengetahui kapan harus menggunakan pengetahuan dan keterampilan yang diperoleh, pengetahuan deklaratif merujuk apa yang harus dan perlu diketahui dan pengetahuan procedural dimaksudkan untuk mengetahui bagaimana menggunakan pengetahuan dan keterampilan seperti yang digambarkan pada tabel 4.2 berikut dimesi proses kognisi :

\begin{tabular}{|l|l|l|l|l|}
\hline $\begin{array}{l}\text { Penget } \\
\text { ahuan }\end{array}$ & $\begin{array}{l}\text { Fakt } \\
\text { ual }\end{array}$ & \multicolumn{1}{|c|}{$\begin{array}{c}\text { Konse } \\
\text { ptual }\end{array}$} & $\begin{array}{l}\text { Prose } \\
\text { dural }\end{array}$ & $\begin{array}{l}\text { Metakog } \\
\text { nisi }\end{array}$ \\
\hline $\begin{array}{l}\text { Memah } \\
\text { ami }\end{array}$ & $\begin{array}{l}\text { Membu } \\
\text { at } \\
\text { Daftar }\end{array}$ & $\begin{array}{l}\text { Mend } \\
\text { eskrip } \\
\text { sikan }\end{array}$ & $\begin{array}{l}\text { Mena } \\
\text { bulasi }\end{array}$ & $\begin{array}{l}\text { Menggun } \\
\text { akan }\end{array}$ \\
\hline $\begin{array}{l}\text { Menget } \\
\text { ahui }\end{array}$ & $\begin{array}{l}\text { Mering } \\
\text { kas }\end{array}$ & $\begin{array}{l}\text { Meng } \\
\text { interp } \\
\text { retasi }\end{array}$ & $\begin{array}{l}\text { Mem } \\
\text { predi } \\
\text { ksi }\end{array}$ & $\begin{array}{l}\text { Melakuk } \\
\text { an }\end{array}$ \\
\hline $\begin{array}{l}\text { Menera } \\
\text { pkan }\end{array}$ & $\begin{array}{l}\text { Mengg } \\
\text { olongk } \\
\text { an }\end{array}$ & $\begin{array}{l}\text { Meng } \\
\text { uji } \\
\text { coba }\end{array}$ & $\begin{array}{l}\text { Meng } \\
\text { hitun } \\
\text { g }\end{array}$ & $\begin{array}{l}\text { Mengkon } \\
\text { truksi }\end{array}$ \\
\hline $\begin{array}{l}\text { Menga } \\
\text { nalisis }\end{array}$ & $\begin{array}{l}\text { Mengat } \\
\text { ur }\end{array}$ & $\begin{array}{l}\text { Menj } \\
\text { elask } \\
\text { an }\end{array}$ & $\begin{array}{l}\text { Mem } \\
\text { bedak } \\
\text { an }\end{array}$ & $\begin{array}{l}\text { Memper } \\
\text { oleh }\end{array}$ \\
\hline
\end{tabular}

\footnotetext{
${ }^{32}$ Nana Sudjana. Penilaian Hasil Proses Belajar Mengajar. ( Bandung: Remaja Rosdakarya, 2012), hal. 22
} 


\begin{tabular}{|l|l|l|l|l|}
\hline $\begin{array}{l}\text { Menge } \\
\text { valuasi }\end{array}$ & $\begin{array}{l}\text { Mengur } \\
\text { ut }\end{array}$ & $\begin{array}{l}\text { Meng } \\
\text { ukur }\end{array}$ & $\begin{array}{l}\text { Meny } \\
\text { impul } \\
\text { kan }\end{array}$ & $\begin{array}{l}\text { Meninda } \\
\text { ki }\end{array}$ \\
\hline $\begin{array}{l}\text { Mencip } \\
\text { takan }\end{array}$ & $\begin{array}{l}\text { Mengg } \\
\text { abungk } \\
\text { an }\end{array}$ & $\begin{array}{l}\text { Mend } \\
\text { esain }\end{array}$ & $\begin{array}{l}\text { Meny } \\
\text { usun }\end{array}$ & $\begin{array}{l}\text { Mengakt } \\
\text { ualis }\end{array}$ \\
\hline
\end{tabular}

8. Faktor yang mempengaruhi Hasil Belajar

\section{Faktor Internal}

Faktor internal yang merupakan faktor yang berasal dari dalam diri peserta didik yang meliputi kecerdasan, minat, perhatian,motivasi belajar, ketekunan, sikap, kebiasan belajar, serta kondisi fisik.

\section{Faktor Eksternal}

Faktor Eksternal yaitu factor yang berasal dari luar diri peserta didik yaitu keluarga, sekolah, dan masyarakat.

\section{B. METODOLOGI}

Jenis penelitian yang peneliti lakukan adalah penelitian tindakan kelas.Penelitan tindakan kelas adalah penelitian yang mengangkat masalahmasalah aktual yang dihadapi guru dilapangan. Arikunto dalam Tukiran, mengartikan bahwa penelitian tindakan kelas merupakan pencermatan terhadap kegiatan belajar berupa sebuah tindakan yang sengaja dimunculkan dan terjadi dalam sebuah kelas secara bersama. ${ }^{33}$

Pola penelitian tindakan kelas yang digunakan dalam penelitian ini adalah pola kolaboratif. Menurut Wina Sanjaya, pola ini biasanya untuk melaksanakan PTK tidak dari guru, akan tetapi dari pihak luar yang berkeinginan untuk memecahkan masalah pembelajaran. PTK dirancang dan dilaksanakan oleh suatu tim yang biasanya terdiri atas guru, kepala sekolah, dan orang lain yang terlibat dalam tim peneliti. Guru berperan hanya sebagai anggota tim peneliti yang berfungsi melaksanakan tindakan seperti yang dirancang oleh tim peneliti. Dengan demikian pada pola ini guru tidak memiliki kesempatan yang luas untuk melakukan tindakan sebab baik perencanaan maupun bagaimana mengimplementasikan tindakan tidak ditentukan oleh guru sendiri melainkan dari tim peneliti. Masalah yang hendak diteliti dengan menggunakan pola ini bisa terjadi masalah yang tidak dihadapi oleh guru secara langsung dan praktis, akan tetapi masalah yang bersifat umum yang ditentukan oleh tim peneliti, walaupun sebenarnya dilakukan untuk membantu guru dalam meningkatkan kualitas pembelajaran.Penelitian tindakan kelas yang peneliti lakukan adalah melakukan kolaborasi antara peneliti dengan guru kelasatau matapelajaran Ilmu Pengetahuan Sosial Kelas VA Sekolah Dasar Negeri 010 Sungai Beringin.

Subjek penelitian ini adalah guru dan siswa kelas VA pada matapelajaran Ilmu Pengetahuan Sosial di Sekolah Dasar Negeri 010 Sungai Beringin. Objek penelitian adalah meningkatkan hasil belajar siswa melalui penerapan model Pembelajaran Cooperative Script 
siswa kelas VA pada mata pelajaran Ilmu Pengetahuan Sosial di SD Negeri 010 Sungai Beringin yang berjumlah 20 orang yang terdiri dari 15 orang laki-laki dan 5 orang perempuan. Jumlah seluruh siswa Sekolah Dasar Negeri $010 \quad$ Sungai Beringin Kelurahan Sungai Beringin adalah 276 Orang dari kelas 1-6 Keberhasilan penerapan model pembelajaran Cooperative Script pada matapelajaran Ilmu Pengetahuan sosial dinyatakan berhasil pada indikator Ketuntasan hasil belajar kognitif siswa mencapai $\geq 75 \%$ dengan KKM 70 pada rata-rata dan ketuntasan belajar siswa mencapai KKM. Begitu juga dalam penerapan model pembelajaran Cooperative Script juga mencapai persentase $\geq 75$ $\%$ dengan jumlah indikator sebanyak 13 butir.

Menurut Hopkins dalam Wina Sanjaya, pelaksanaan penelitian tindakan dilakukan membentuk spiral yang dimulai dari merasaakan adanya masalah,melaksanakan tindakan, melakukan observasi, mengadakan refleksi, melakukan rencana ulang Seperti yang diuraikan dalam model Penelitian tindakan kelas, dalam setiap putaran PTK dilakukan empat kegiatan yakni Perencanaan PTK, tindakan, observasi, dan refleksi Teknik pengumpulan data adalah cara yang digunakan peneliti untuk mengumpulkan data penelitian dengan tes, observasi dan dokumentasi. Teknik analisis yang digunakan peneliti dalam penelitian ini adalah Analisis Kuantitatif yang digunakan untuk mendeskripsikan hasil belajar kognitif dalam hubungannya dengan penguasaan materi yang diajarkan oleh guru melalui penerapan model pembelajaranCooperative Script pada mata pelajaran Ilmu Pengetahuan Sosial.Analisis kuantitatif pada penelitian ini analisis terhadap hasil belajar kognitif siswa secara individual maupun secara klasikal. Selain itu juga menggunakan analisis kualitatif.

\section{PEMBAHASAN}

1. Hasil observasi dan catatan lapangan penelitian Prasiklus

Berdasarkan catatan lapangan dan hasil pengamatan peneliti terhadap pelaksanaan pembelajaran ilmu pengetahuan sosial dikelas VA tanggal 19 Juli 2018 ada berbagai temuan yang peneliti temui yaitu kegiatan pembelajaran membahas tentang Tema 1 sub tema 1 membahas tentang letak Geografis wilayah indonesia yang terdapat pada pembelajaran 3 Tema 1 (Organ Gerak Hewan dan Manusia) dengan alokasi waktu 2x35 menit. Guru melaksanakan kegiatan dengan tiga tahap yaitu kegiatan awal, kegiatan inti dan kegiatan penutup. Guru masih belom maksimal dalam menggunakan model serta metode pembelajaran yang bervariasi, metode atau model pembelajaran yang digunakan adalah metode ceramah, dan metode tanya jawab serta tes lisan. Selain hal-hal tersebut diperoleh juga siswa yang 
masih ribut ketika guru menjelaskan yang ditandai ketika guru menjelaskan $50 \%$ siswa masih ribut, ketika guru melakukan tanya jawab secara lisan sebagai evaluasi atas seberapa pahamnya siswa terhadap materi yang telah dipelajari pada pertemuan tersebut dari 20 orang siswa hanya 5 orang siswa yang mampu menjawab sedangkan yang lainya hanya diam saja.

2. Hasil Belajar Penelitian Prasiklus

Hasil yang diperoleh dari kegiatan tes yang diberikan oleh peneliti yang berkolaborator dengan guru kelas VA sekaligus guru matapelajaran Ilmu pengetahuan sosial terhadap 20 orang siswa dengan materi pada pembelajaran 3 tema 1 subtema 1 tentang Letak Geografis Wilayah Indonesia sebagai berikut yang diperoleh dari 15 soal yang terdiri dari 15 soal. Berikut hasil belajar siswa kelas VA pada pelaksaan tes prasiklus materi tentang Letak Geografis Indonesia dengan KKM 70.

Persentase Ketuntasan Hasil Belajar Siswa Pada Tes Prasiklus Pada Hari Senin Tanggal 19 Juli 2018 Pada Mata Pelajaran Ilmu Pengetahuan Sosial Tahun 2018/2019

\begin{tabular}{|c|c|c|c|}
\hline No. & $\begin{array}{c}\text { Hasil } \\
\text { Belajar }\end{array}$ & Jumlah & Persentase \\
\hline 1. & Tuntas & 6 Orang & $30 \%$ \\
\hline 2. & $\begin{array}{c}\text { Tidak } \\
\text { Tuntas }\end{array}$ & 14 Orang & $70 \%$ \\
\hline \multicolumn{2}{|c|}{ Jumlah } & 20 Orang & $100 \%$ \\
\hline
\end{tabular}

Grafik 1 persentase hasil ketuntasan belajar prasiklus siswa kelas VA pada matapelajaran Ilmu Pengetahuan Sosial

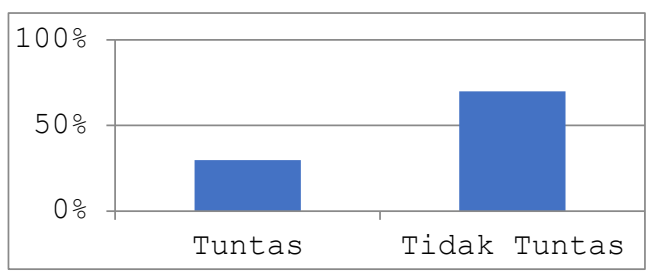

Berdasarkan Hasil pelaksanaan penelitian tindakan kelas diatas dapat diperoleh hasil belajar siswa kelas VA pada matapelajaran Ilmu Pengetahuan sosial berupa Rata-rata kelas pada kegiatan tes pemberian soal pelaksanaan siklus 1 dan ketuntasan belajar siswa pada prasiklus dan siklus 1 sebagai berikut :

\begin{tabular}{|c|c|c|c|}
\hline No & Kegiatan & $\begin{array}{c}\text { Rata- } \\
\text { rata }\end{array}$ & Keterangan \\
\hline 1. & Prasiklus & 56,25 & $\begin{array}{c}\text { Kurang } \\
\text { baik }\end{array}$ \\
\hline 2. & Siklus 1 & 69,00 & Cukup \\
\hline
\end{tabular}

Berdasarkan tabel diatas rata-rata klasikal yang diperoleh oleh siswa kelas VA Pada matapelajaran IPS mengalami peningkatan dari prasiklus menuju siklus 1, yaitu dari 56,25 menjadi 69,00 dengan interval nilai 60-69 kategori cukup baik.

Rata-rata hasil belajar siswa kelas VA pada Prasiklus dan siklus 1 pada matapelajaran IPS 


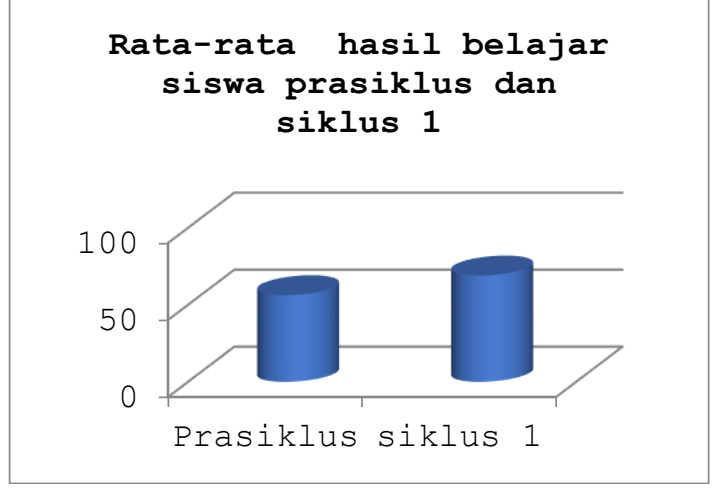

Berdasarkan pelaksanaan diatas juga dapat diperoleh ketuntasan belajar siswa yang tuntas dan tidak tuntas dari prasiklus hingga siklus 1 yang diperoleh dari hasil tes siswa kelas VA

\begin{tabular}{|c|c|c|c|c|c|}
\hline No & $\begin{array}{c}\text { Kegia } \\
\text { tan }\end{array}$ & $\begin{array}{c}\text { Tun } \\
\text { tas }\end{array}$ & P & $\begin{array}{c}\text { Tidak } \\
\text { Tuntas }\end{array}$ & P \\
\hline 1. & $\begin{array}{c}\text { Prasi } \\
\text { klus }\end{array}$ & 6 & $30 \%$ & 14 & $70 \%$ \\
\hline 2. & $\begin{array}{c}\text { Siklu } \\
\text { s 1 }\end{array}$ & 11 & $55 \%$ & 9 & $45 \%$ \\
\hline
\end{tabular}

Persentase Ketuntasan Belajar Siswa Pada Prasiklus dan Siklus 1

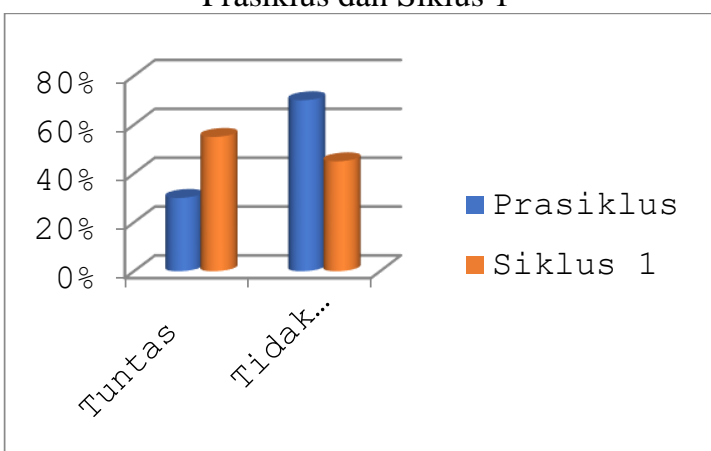

Berdasarkan grafik diatas dapat terlihat bahwa ketuntasan belajar siswa dari prasiklus mengenai tes tertulis siswa mengalami peningkatan dari $30 \%$ menjadi $55 \%$ siswa yang tuntas dan siswa yang tidak tuntas dari $70 \%$ menjadi $45 \%$.

Untuk mengetahui perbandingan hasil belajar siswa Kelas VA pada tes tertulis Matapelajaran Ilmu Pengetahuan Sosial siklus 1 dan siklus 2 melalui hasil rata-rata kelas yang diperoleh siswa dan ketuntasan belajar secara keseluruhan sebagai berikut :
Rata-rata Klasikal Hasil Belajar Siswa Kelas VA Pada Matapelajaran Ilmu Pengetahuan Sosial Siklus 1 dan 2

\begin{tabular}{|c|c|c|c|}
\hline No. & $\begin{array}{c}\text { Kegiata } \\
\mathrm{n}\end{array}$ & $\begin{array}{l}\text { Rata- } \\
\text { rata }\end{array}$ & Keterangan \\
\hline 1. & Siklus 1 & 69,00 & Cukup baik \\
\hline 2. & Siklus 2 & 91,00 & Sangat baik \\
\hline
\end{tabular}

Berdasarkan hasil rata-rata kelasikal ulangan diatas hasil ulangan siswa kelas VA pada matapelajaran IPS dari siklus 1 ke siklus 2 mengalami peningkatan dari 62,30 menjadi 83,10 dengan kategori cukup baik menjadi sangat baik.

Grafik 4 rata-rata klasikal tes siswa kelas VA pada subtema 1 dan 2 mata pelajaran Ilmu Pengetahuan Sosial siklus 1 dan 2

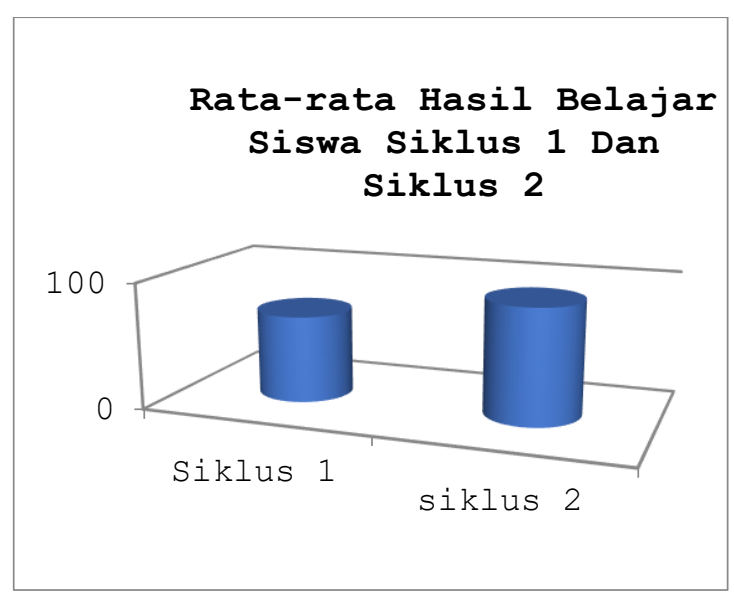

Ketuntasan belajarkelas VA Pada matapelajaran Ilmu Pengetahuan Sosial siklus 1 dan 2

Persentase Ketuntasan Belajar Kelas VA Pada Matapelajaran Ilmu Pengetahuan Sosial Siklus 1 dan Siklus 2

\begin{tabular}{|c|c|c|c|c|c|c|}
\hline $\begin{array}{l}\mathbf{N} \\
\text { o. }\end{array}$ & $\begin{array}{l}\text { Kegi } \\
\text { atan }\end{array}$ & $\mathbf{T}$ & $\mathbf{P}$ & Ket & TT & $\mathbf{P}$ \\
\hline 1. & $\begin{array}{l}\text { Sikl } \\
\text { us } 1\end{array}$ & 11 & $\begin{array}{l}55 \\
\%\end{array}$ & $\begin{array}{c}\text { Cukup } \\
\text { baik }\end{array}$ & 9 & $\begin{array}{l}45 \\
\%\end{array}$ \\
\hline 2. & $\begin{array}{l}\text { Sikl } \\
\text { us } 2\end{array}$ & 18 & $\begin{array}{l}90 \\
\%\end{array}$ & $\begin{array}{c}\text { Sangat } \\
\text { baik }\end{array}$ & 2 & $\begin{array}{l}10 \\
\%\end{array}$ \\
\hline
\end{tabular}


Grafik 5 Ketuntasan Belajar Siswa Kelas VA Pada Tes Tertulis Siklus 1 dan 2 Pada Mata Pelajaran Ilmu Pengetahuan Sosial

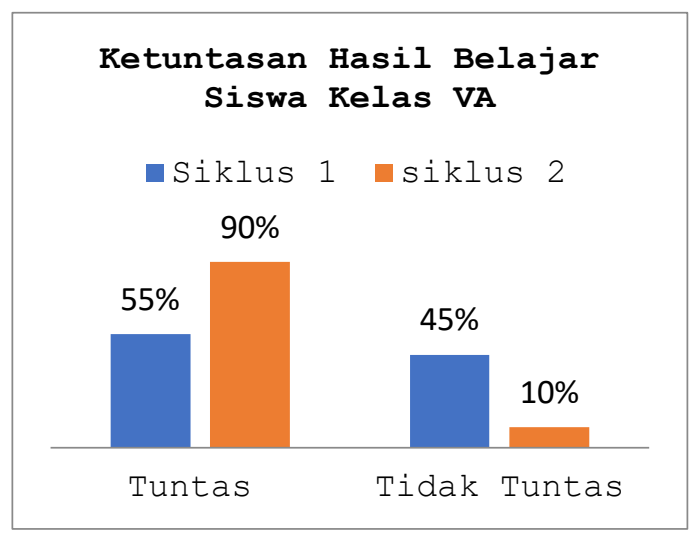

Penyajian Data Hasil Observasi Penerapan Model Pembelajaran Cooperative Script Oleh Kolaborator Pada MataPelajaran Ilmu Pengetahuan Sosial Siklus 1 Dan 2

Penerapan model pembelajaran Cooperative Script yang dilaksanakan oleh kolaborator pada pertemuan 1 dan 2 setiap siklus diamati melalui lembar observasi oleh peneliti dengan menggunakan alternatif jawaban 1,2,3,4,5 dengan keterangan sebagai berikut :

$$
\begin{aligned}
& \text { 1= Tidak Baik } \\
& 2=\text { Kurang Baik } \\
& 3=\text { Cukup Baik } \\
& 4=\text { Baik } \\
& 5=\text { Sangat Baik }
\end{aligned}
$$

Berikut tabel penerapan Model Cooperative Script oleh kolaborator:

Persentase Penerapan Model Cooperative ScriptPada MataPelajaran Ilmu Pengetahuan Sosial Kelas VA Siklus 1 Dan Siklus 2

\begin{tabular}{|c|l|c|c|}
\hline No & Kegiatan & $\begin{array}{c}\text { Persenta } \\
\text { se }\end{array}$ & $\begin{array}{c}\text { Keteranga } \\
\mathrm{n}\end{array}$ \\
\hline 1 & $\begin{array}{l}\text { Siklus 1 } \\
\text { pertemuan 1 }\end{array}$ & $72,83 \%$ & Baik \\
\hline 2 & $\begin{array}{l}\text { Siklus 1 } \\
\text { pertemuan 2 }\end{array}$ & $75,78 \%$ & Baik \\
\hline
\end{tabular}

\begin{tabular}{|c|l|c|c|}
\hline $\begin{array}{c}\text { Rata- } \\
\text { rata }\end{array}$ & $73,83 \%$ & Baik \\
\hline 2 & $\begin{array}{l}\text { Siklus 2 } \\
\text { pertemua 1 }\end{array}$ & $81,53 \%$ & $\begin{array}{c}\text { Sangat } \\
\text { Baik }\end{array}$ \\
\hline & $\begin{array}{l}\text { Siklus 2 } \\
\text { pertemuan 2 }\end{array}$ & $92,30 \%$ & $\begin{array}{c}\text { Sangat } \\
\text { Baik }\end{array}$ \\
\hline $\begin{array}{c}\text { Rata- } \\
\text { rata }\end{array}$ & $86,91 \%$ & $\begin{array}{c}\text { Sangat } \\
\text { Baik }\end{array}$ \\
\hline \multicolumn{3}{|c|}{ Berdasarkan tabel diatas dapat }
\end{tabular}
diperoleh bahwa hasil penerapan Model Pembelajaran Cooperative Script mengalami peningkatan dari siklus $1 \mathrm{ke}$ siklus 2 dengan kategori baik menjadi sangat baik yaitu $73,83 \%$ menjadi $86,91 \%$.

Grafik 6 peningkatan Hasil observasi penerapan Model Pembelajaran Cooperative Script siklus 1 dan 2

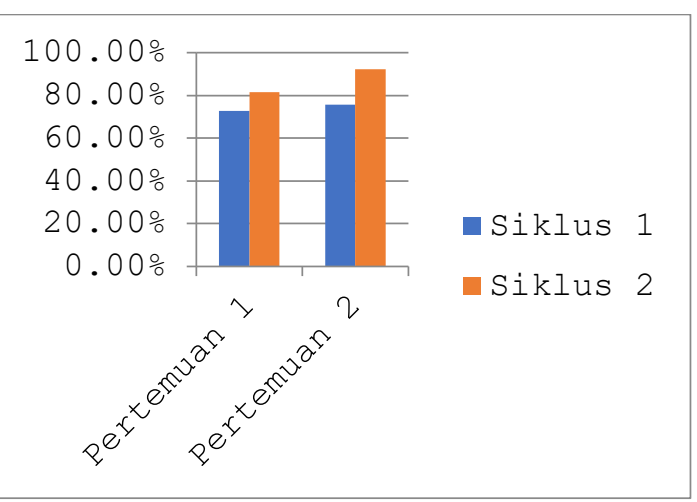

a. Hasil belajar siswa kelas VA pada Matapelajaran IPS prasiklus,siklus 1 dan siklus 2

Data hasil belajar ini diperoleh melalui hasil lembar Soal tes yang diberikan kepada siswa pada setiap siklus. Data ini diambil mengenai hasil belajar berupa nilai tes yang terdapat pada sub tema 1 yang terdapat dalam tema 1 tentang Kondisi Geografis Wilayah Indonesia, letak geografis wilayah indonesia, kondisi geografis wilayah indonesia berdasarkan peta dan Kenampakan alam dan buatan yang termuat dalam Tema 1 dengan 
Kompetensi Dasar 3.1. Berdasarkan hasil tes prasiklus, siklus 1 dan siklus 2 mengalami peningkatan dari 56,25, 69,00menjadi 91,00 dengan Kategori sangat baik. Berikut tabel penyajian data rata-rata hasil belajar siswa kelas VA prasiklus, siklus 1 dan 2 :

Rata-Rata Hasil Belajar Siswa Kelas VA Pada Mata Pelajaran Ilmu Pengetahuan Sosial Prasiklus, Siklus 1 Dan Siklus 2

\begin{tabular}{|c|c|c|c|}
\hline No & Kegiatan & Rata-rata & Keterangan \\
\hline 1 & Prasiklus & 56,25 & Kurang baik \\
\hline 2 & Siklus 1 & 69,00 & Cukup Baik \\
\hline 3 & Siklus 2 & 91,00 & Sangat Baik \\
\hline
\end{tabular}

Apabila digambarkan peningkatan rata-rata hasil belajar tersebut dapat digambarkan dengan grafik berikut :

Grafik 7 Rata-rata hasil belajar siswa kelas VA pada matapelajaran Ilmu

Pengetahuan Sosial prasiklus, siklus 1 dan siklus 2

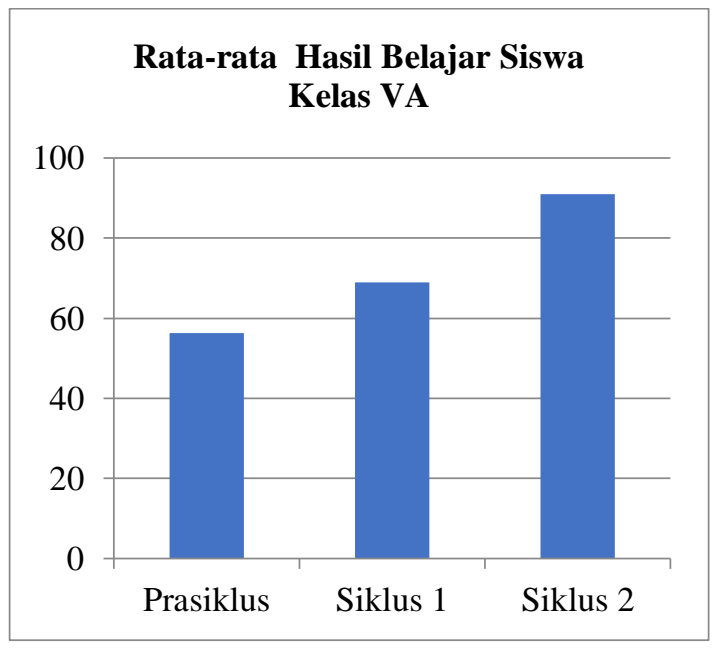

Selain diperoleh hasil rata-rata hasil belajar prasiklus, siklus 1 dan siklus 2 juga diperolah persentase ketuntasan belajar siswa dalam memahami materi pelajaran IPS yang telah dipelajari pada subtema 1 dan 2 .
Persentase Ketuntasan Belajar Siswa Kelas VA Pada Matapelajaran Ilmu Pengetahuan Sosial Siklus Prasiklus, Siklus 1 Dan Siklus 2

\begin{tabular}{|l|c|c|c|}
\hline Kegiatan & $\begin{array}{c}\text { Hasil } \\
\text { Belajar }\end{array}$ & Jumlah & Persentase \\
\hline Prasiklus & Tuntas & 6 Orang & $30 \%$ \\
\cline { 2 - 4 } & $\begin{array}{c}\text { Tidak } \\
\text { Tuntas }\end{array}$ & 14 Orang & $70 \%$ \\
\hline \multirow{2}{*}{ Siklus I } & Jumlah & 20 Orang & $100 \%$ \\
\cline { 2 - 4 } & Tuntas & 11 Orang & $55 \%$ \\
\hline \multirow{2}{*}{ Siklus II } & $\begin{array}{c}\text { Tidak } \\
\text { Tuntas }\end{array}$ & 9 Orang & $45 \%$ \\
\cline { 2 - 4 } & Jumlah & 20 Orang & $100 \%$ \\
\cline { 2 - 4 } & $\begin{array}{c}\text { Tidak } \\
\text { Tuntas }\end{array}$ & 2 Orang & $10 \%$ \\
\hline & Jumlah & 20 Orang & $100 \%$ \\
\hline
\end{tabular}

Berdasarkan tabel tersebut dapat dilihat bahwa ketuntasan belajar siswa mengalami peningkatan dari prasiklus, siklus 1 dan siklus 2 yaitu dari $30 \%, 55$ $\%$ dan menjadi $90 \%$ dengan kategori sangat baik.

Peningkatan ketuntasan belajar siswa tersebut dapat digambarkan pada grafik berikut :

Grafik 8 persentase Ketuntasan belajar siswa kelas VA pada matapelajaran Ilmu Pengetahuan Sosial siklus prasiklus, siklus 1 dan siklus 2

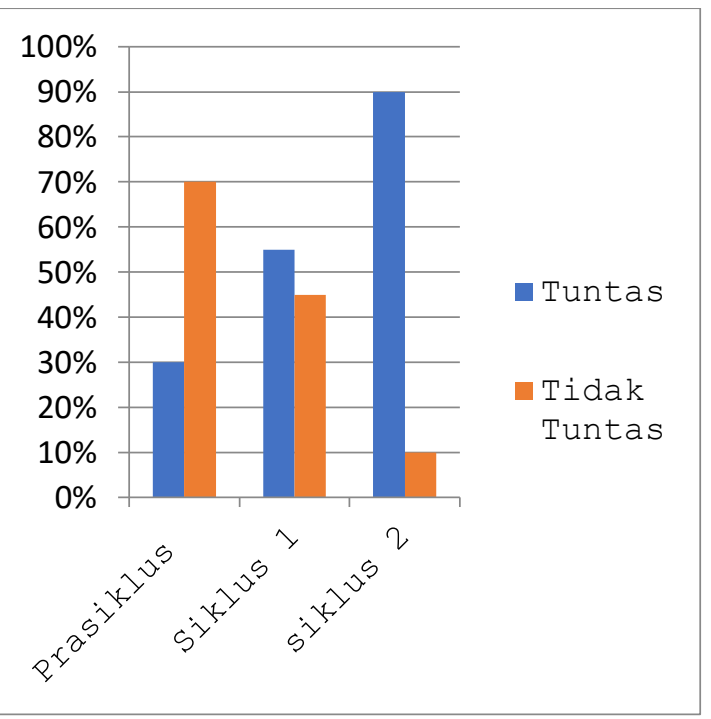

Berdasarkan uraian diatas dapat disimpulkan bahwa melalui penerapan model pembelajaran Cooperative Script 
hasil belajar siswa mengalami peningkatan dari prasiklus, siklus 1 dan siklus 2 sesuai target tujuan penelitian.

Hasil Observasi penerapan model Pembelajaran Cooperative Script pada matapelajaran Ilmu Pengetahuan Sosial di Kelas VA Sekolah Dasar Negeri 010 Sungai Beringin siklus 1 dan siklus 2.

Grafik 9Peningkatan Penerapan model Pembelajaran Cooperative Script pada MataPelajaran Ilmu Pengetahuan Sosial Kelas VA

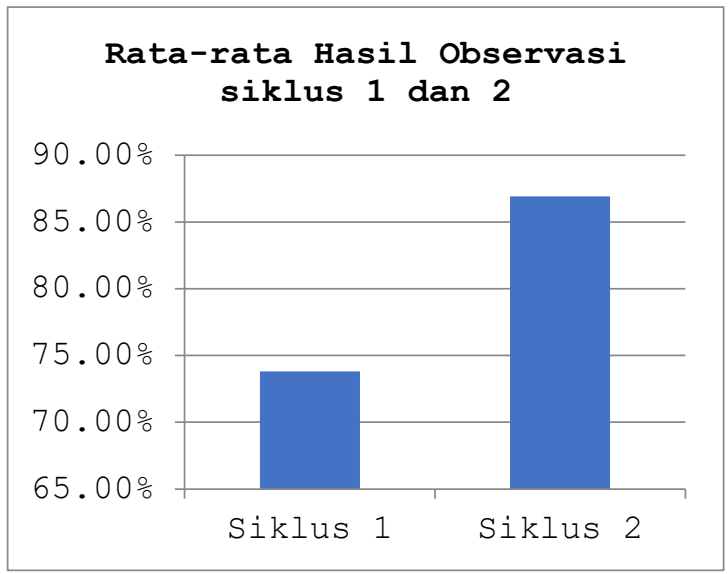

Berdasarkan grafik di atas dapat dilihat bahwa penerapan model Pembelajaran Cooperative Script dilaksanakan dengan sangat baik oleh kolaborator yaitu pada siklus 1 mencapi $73,83 \%$ dengan kategori sangat baik dan siklus 2 mencapai $83,10 \%$ dengan kategori sangat baik dan mengalami peningkatan pada setiap siklus nya dari siklus 1 ke siklus 2 .

\section{KESIMPULAN}

Berdasarkan pembahasan dan hasil penelitian pada Bab IV dapat disimpulkan bahwa:

1. Hasil belajar siswa kelas VA pada matapelajaran Ilmu Pengetahuan Sosial di Sekolah Dasar Negeri
010 Sungai Beringin mengalami peningkatan dari awal prasiklus hingga siklus 2 yaitu rata-rata hasil belajar prasiklus mencapai 56.25 dengan kategori kurang baik, ratarata siklus 1 mencapai 69,00 dengan kategoricukup baik, dan siklus 2 mencapai 91,00 dengan kategori sangat baik. Kemudian pencapaian ketuntasan belajar siswa yaitu prasiklus mencapai 30 $\%$, Pada siklus 1 menghasilkanpersentase $55 \%$, serta siklus 2 meningkat kembali dan mencapai target mencapai persentase $90 \%$ sangat baik.

2. Penerapan model pembelajaran Cooperative Script pada matapelajaran Ilmu pengetahuan yang diterapkan oleh kolaborator mengalami peningkatan dari siklus 1 dan 2 yaitu $73,83 \%$ dengan kategori baik dan $86,91 \%$ dengan kategori sangat baik. Artinya, guru mampu melaksanakan model pembelajaran Cooperative Script dengan sangat baik.

3. Penerapan model pembelajaran Cooperative Script pada matapelajaran Ilmu Pengetahuan Sosial dapat meningkatkan hasil belajar siswa kelas VA di Sekolah Dasar Negeri 010 Sungai Beringin

\section{REFERENSI}

Abdul Majid dan Chairul Rochman. (2014). Pendekatan Ilmiah dalam Implementasi Kurikulum 2013. Bandung: Remaja Rosdakarya.

Agus Suprijono. (2013). Cooperative Learning. Yogyakarta: Pustaka Pelajar. 
Ahmad Susanto. (2013). Teori Belajar dan Pembelajaran. Jakarta: Prenadamedia Group.

Anas Sudijono.(2006). Pengantar Evaluasi Pendidikan. Jakarta: Raja Grafindo Persada.

Asih.(2002). Strategi Pembelajaran Bahasa Indonesia. Bandung: Pustaka Setia.

Cahyo, dkk.(2017). Tematik Kelas V Tema 1 Organ Gerak Manusia dan Hewan untuk SD/MI. Bandung: Citra Pustaka.

Hamdani.(2011). Strategi Belajar Mengajar. Bandung: Pustaka Setia.

Hamzah B.Uno.(2006). Perencanaan Pembelajaran. Jakarta: Bumi Aksara.

Irene MJA, dkk.(2017). Buku Penilaian BUPENA Untuk SD/MI Kelas V Jilid 5A. Jakarta: Erlangga.

Isjoni.(2009). Pembelajaran Kooperatif. Yogyakarta: Pustaka.

Maryanto. (2017. Buku Guru Tema 1 Organ Gerak Manusia dan Hewan Kurikulum 2013 revisi 2017.

Miftahul Huda.(2014). Model-model Pengajaran dan Pembelajaran. Yogyakarta: Pustaka Pelajar. cetakan V.

Muhammad Yaumi. (2004). Prinsipprinsip Desain Pembelajaran disesuaikan Kurikulum 2013. Jakarta: Prenadamedia Group.

Nana Sudjana.(2012). Penilaian Hasil Proses Belajar Mengajar. Bandung: Remaja Rosdakarya.

Sabiyarti. (2017). Ayo Belajar Tema 1 Organ Gerak Hewan dan Manusia. Jakarta: Erlangga.

Sapriya.(2009). Pendidikan IPS. Bandung: Remaja Rosdakarya. Cet 1.

Tukiran Taniredja.(2010). Penelitian Tindakan Kelas. Bandung: Alfabeta.

Wina Sanjaya.(2009). Penelitian Tindakan Kelas. Jakarta: Kencana Prenada Media Group. 